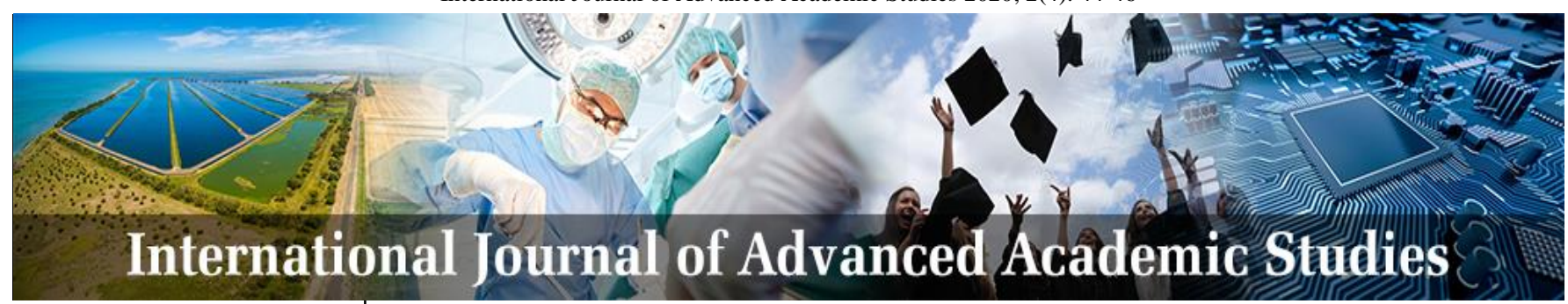

E-ISSN: 2706-8927

P-ISSN: 2706-8919

www.allstudyjournal.com

IJAAS $2020 ; 2(4): 44-46$

Received: 09-08-2020

Accepted: 11-09-2020

Yalda Waez Masih

Assistant Professor, Lecturer

of Foreign Department,

Faculty Electro-Mechanic,

Kabul Polytechnic University, Afghanistan
Corresponding Author: Yalda Waez Masih Assistant Professor, Lecturer of Foreign Department, Faculty Electro-Mechanic, Kabul Polytechnic University, Afghanistan

\section{Role of teacher in teaching process}

\author{
Yalda Waez Masih
}

DOI: https://doi.org/10.33545/27068919.2020.v2.i4b.324

\begin{abstract}
This article mainly focuses how a teacher teaches the students and how students learn based on the teacher teaching process. Before talking about the role of a teacher it is important to know the definition of the role that what is it and how it helps the teachers in their teaching processes. In my points of view role is the character or an apart that someone do to complete something. For example, when I manage my class is one of the roles that I have in my teaching process. However, teacher has several roles in teaching process, but I want to discuss on two of them that I think is really important in the teaching process and develop student language skill. They are such as: being as a manager and a facilitator.
\end{abstract}

\section{Keywords: Teacher and Teaching Process}

\section{Introductions}

Teaching is an enduring occupation which is the basis of all other careers. Teachers are the important leaders of a complete and tolerant culture. Professional lecturers plant seeds for presenting intelligent doctors, intelligent cost accountant, intelligent scientists and eventually, best citizens. Teachers endure the load and accountability of training and away from the students' parents, are the key basis of understanding and beliefs for future generation. The significance of a teacher as a maker of our future generations needs only the best, the most intelligent, the most capable members of society to be allowed to qualify for this honorable occupation. So, this article will clarify the teachers' roles in the teaching process and several steps which are included in this study are as: Literature review, results, discussion, conclusion and references.

\section{Literature Review}

In the part of literature review it is needed to first clarify role itself and then talk about the teacher role and its responsibility. Role is the actor's part; it means that while a person function or does something, also means what whatever a person select or does. The above definition was given by the Concise Oxford Dictionary (1982) ${ }^{[2]}$, but in our daily lives we fulfill roles that have features of all these defining characteristics. We have roles in society in which that we play parts. Some of the roles are hard to avoid. For example, father and some responsibilities may be push upon us by conditions, for example, students of the school. On other ways, we select many of the roles that we continue in our lie as the teacher job.

For clarifying and better understanding first of all we need to understand the word teacher itself first and after that we should have another explanation and clarification about the teacher. So:

According to the Enciklopedijski recnik pedagogije (1963) ${ }^{[4]}$ ideas teachers refer to the person who conducts classes. To develop his idea Pedagoska Enciklopedija (1989) ${ }^{[8]}$ also explained that teacher is someone who has been accepted eligibly by education authority and society to up bring the children, youths and adults. He also appreciates social aims and tasks of education.

Teacher helps his/her learners to work with and to motivate their interest for the learning process. It is joyful, with having a nice condition or hummer, deep and friendly situation. Reports based on the society for the learners, patience, calmness, their respects and responsibilities of the students help them to prevent sarcasm and use of the bad words.

In addition, Bognar and Matijevic (1993) ${ }^{[1]}$ claimed that a teacher is an organizer and a leader in the process of the education; because the teacher knows how to guide, how to 
didactics in his/her learning process as well as knows the method of teaching and has a good experience in a educational field.

sBased on the Murati (2014) points of view when talking about the role of the teacher as the educator we must realize that now days desires and situations everyday need more and more to act as a teacher, friend, counseling, facilitator, supporter, manager, ideal, viewer, stimulant, reliable and Certainly to associate with children. Murati also described that teacher is responsible for planning a good learning process for the learners and he is also responsible for the managing of the class and design and clear the time for better teaching and learning process.

The teacher work in education field should be based on sincerity, desire and love to the students and also for the based students' practices and their professions.

So, a teacher is someone who must be formed with a good personality to have the ending of the sophistication, attraction, humility and compassion, gentility and attention to students. In the process or field of the education part there should not be any bias, anxiety and being lack of students' interest and being dis motivated. Educational program for the gaining of the success from the teacher required preferences, attentions and skills of the teaching in the teaching fields.

Nonetheless from some the warranties of lecturers in process of the teaching and learning parts, the key work of the teacher is the educational sections. For having successful realization of the teacher work in educational field is needed the teacher reflection of his/her work qualities which prove the abilities and great pedagogical knowledge and their practical works for having a proper teaching environment. Teacher moral obligation and duty is her/his preservation of national and community standards.

Therefore, Osho (1997) [7] stated that educational developments are mainly consists of three limits: student teacher and parents. The teacher plays the essential role in learners' education. A teacher plays different roles during teaching learning process to realize responsibilities assigned to them.

The students are like rose-bud plants. The teacher is like a friend, philosopher and a guide for the students. Here the researcher had tried to find out the roles of teachers discussed by Rajneesh (1988) and they are as: (1) Judge actions, and correct them, and don't correct them according to tradition, (2) Should not judge individuals, (3) Put the student on the right path through love and compassion, (4) Channelize the energy of the students, (5) Help the students to find right paths through love, (6) A guide to find the latest information on the subject, (7) A guide to show the right channel, how to use the computer, how to find the latest book, (8) Arise dormant questioning in children, awaken inquisitiveness and make children fearless and courageous enough to find solutions for themselves, (9) Love children, (10) Learn from students, (11) Help students' doubts disappear, and make them more knowledgeable, (12) Create the right atmosphere to gain self-respect and to give students an acquaintance with the methods for going inwards, (13) Listen the students patiently, (14) Should not think himself/herself as a teacher but a guide, (15) A help to the student to start moving on their own, (16) Help the students to be more creative, (17) Help students to be completely lost, (18) A helper to a student when he is doing any creative work, (19) Help students to be creative ,joyous and cheerful, (20) Should not expect from children, (21) A friend, an elder brother to the students, (22) The real teacher does not inform; he transforms, (23) Help students to grow but never curb their freedom, (24) Discipline the students keeping in mind one thing that discipline is a meansfreedom is the end, (25) Teach the students how to deny, (26) An elder brother to the students, (27) Teacher should not order, (28) Persuade, explain and make the students happy, (29) Help students to be alive, authentic, loving, flowing, and life takes care, (30) A great teacher is one who uses all kinds of living situations to provoke awareness in students.

To support the above ideas Starkey (2012) described that in a building of each nation and every student a teacher is the key element and is a wealth for our country skilled. Each educated and clever student must be making and form by the lecturer. Therefore, it is needed for the teacher to think positive how to teach and plan to make the students clever and intelligent. And make a situation to involve whole students in the learning process and this situation can be called a global era or situation. And in this era the role of the teacher is changing and can play different roles for having better teaching process. Teacher needs understanding and construction on four bases of the education, for example, learning for living, learning for knowing, learning for doing, and learning for being. The role of teacher is nowadays changed as a smart and active learning methodology and approaches.

A teacher has a key role for the assisting of the students in the active learning approaches. So, based on the teacher assistance the class environment also changes. Indeed, the active learning approach mostly focuses on the learners helps and to ease them the learning environments. It has different activities as: having group work presentations, readings, mind mapping activities and involving students in each lessons and class activities. Based on the Starkey (2012) explanation this kind of activities are useful for finding creative students and their talents.

\section{Result}

In a result, first I can say that a teacher should be a good manager because management plays a key role in the teaching process. If a teacher is very intelligent and is well prepared and does not have the skill of managing the class, teaching will not take place effectively because teacher explains the lesson without caring about the discipline of the class, about the time and mostly students will not listen carefully for the teacher who are at the back of the class. In order to manage the class effectively before starting of the lesson teacher should be able to control the whole class and bring a positive and friendly environment. It can be possible if the teacher knows: how to arrange the students in the class, which role should be complete by teacher or which should be complete by the students, how to plan a lesson, how to start the lesson, how to treat with students and how to keep calm the class environment, also, teacher should know how much time should be seated for each activities or parts while teach in the class. if the teacher considered the above mentioned points in his/her teaching process can teach the students comprehensively and without waste of time and his/her teaching become successful and achieve the aims of his/her teaching otherwise, teacher waste the time and will not have any effects on the students learning process. 
Next, I would like to discuss about the facilitator which plays a basic role in the teaching process and have a good effect on students learning process. I learn that being facilitator is good then being a teacher, because facilitator can help students in each field or aspects of their education. And in my opinion a facilitator can be a problem solver; it means that whenever students face with any problem or difficulty during their learning, so facilitator helps them in order to solve their problem. And show them the way that how they should learn and solve their problem. For example, when a student read the book and face with a vogue word and do not understand the meaning of that word, in this place when the person who teach them and answer him the question is a facilitator. According to Knowles et al. (2012) ${ }^{[5]}$ the facilitator role may appear to be more casual, but actually requires increased attentiveness to what is happening in individual and groups of learners. I agree with their idea, however, works of the facilitators mostly seems easier, but in reality it is very hard. Facilitator manages the class activities, set the groups, manages the time for the learning and guide the students for their learning. Nowadays, in some of Afghanistan Universities mostly the teachers are turned from being a teacher to the facilitator. Most of the teachers do not give lecture for the students, just guide the students that what and how they should learn. Also, a facilitator prepare the material for the students and ask them to take complete part in each activities and him/herself just lead them that how they should work and learn the lesson.

\section{Conclusion}

In conclusion, I can say that teacher has many basic roles in the teaching process that can really help the learners to learn effectively. In this article I have discussed only on some roles which is necessary in the teacher teaching process and on students' academic performances.

The teacher who plays the role of manager can manage the whole learning process successfully and help the learners to overcome all learning process in a very best way. Teacher also plays a role of active guide to make the learning process happen actively and involve them in the whole learning process and make a clear learning environment. In addition, teacher is a main factor in the teaching and learning process that no one can take his/her place. Overall, I recommend some ways for the teachers to continue with their students to help them to engage self- confidence and make them be more active and creative. First, a teacher should come early to the class and show the students that how being punctual is important. Second, A teacher first should respect the whole educational process him/herself because he/she is the model for the students. Finally, a teacher needs to be well prepared and make the whole learning environment easy for the students.

\section{Reference}

1. Bognar L, Matijevic M. Didaktika, Skolska knjiga, Zagreb 1993.

2. Concise Oxford Dictionary 1982.

3. Dykstra C. Christian education and the moral life: An evaluation of an alternative to Kohlberg. (Unpublished doctoral dissertation.) Princeton Theological Seminary (available through Xerox-University Microfilms) 1978.

4. Enciklopedijski recnik pedagogije. Matica Hrvatska, Zagreb 1963.
5. Knowles MS, Holton EF, Swanson RA. The adult learner. London: Routledge 2012.

6. Murati R. The Role of the Teacher in The Educational Process. New Horizons in Education 2015;5(2).

7. Osho. Revolution in Education, New Age International Publishers, New Delhi 1997, p70.

8. Pedagoska Enciklopedija. Zavod za udžbenike i nastavna sredstva, Beograd 1989.

9. Rajneesh. The Invitation, Rebel Publishing House, West Germany 1987, P262.

10. Starkey L. Teaching and learning in the digital age Rutledge, New York Nankar 2012.

11. Shirode S. current trends in education. Nutan publication, Pune 2009. 